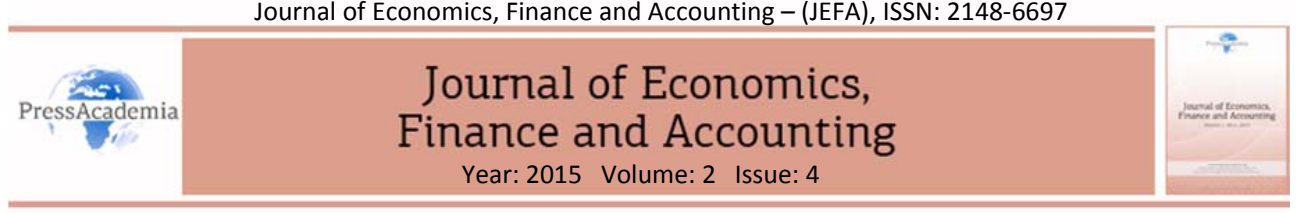

\title{
THE RELATIONSHIP BETWEEN HUMAN RESOURCES FOR HEALTH AND DEVELOPMENT LEVELS OF PROVINCES
}

\section{DOI: 10.17261/Pressacademia.2015424375}

\author{
Serap Taskaya ${ }^{1}$, Bayram Sahin ${ }^{2}$, Mustafa Demirkıran ${ }^{3}$,Pınar Balcik Yalcin ${ }^{4}$ \\ ${ }^{1}$ Aksaray University. seraptaskaya@yahoo.com \\ ${ }^{2}$ Hacettepe University. baysahin@hacettepe.edu.tr \\ ${ }^{3}$ Suleyman Demirel University. m-demirkiran@hotmail.com \\ ${ }^{4}$ Hacettepe University. pyalcin@ hacettepe.edu.tr
}

\section{Keywords}

Economic

development, provinces, human resources for health, correlation analyzes, pharmacist.
JEL Classification A12, I15, I31

\section{ABSTRACT}

The sizes of human resources for health are the most important indicators which are used to determine the level of health status among countries, regions or provinces. The aim of this study was to assess the relationship between health workforce to population ratios and economic development ranking of provinces. The data on economic development ranking of provinces were obtained from "Socio-Economic Development Ranking of Provinces and Regions "published in 2013 by the Republic of Turkey Ministry of Development and "Research on Development Level of Provinces with 2010 and 2012 Data" conducted by Turkey Isbank in 2014. Health workforce to population ratios by provinces were obtained from the official website of Turkish Statistical Institute. The correlation analyzes indicated that, it was highly correlation between the economic development level and number of dentist per 10000 population $(r=-0.890$ and- -0.792$)$ and number of pharmacist per 10000 population $(r=-0.810$ and -0.684$)$ and moderate correlation between the level of economic development ranking and with the number of physician per 10000 population ( $r=-0.680$ and -0.698 ). The correlation between nurse to population ratio $(r=-0.507$ and -0.422$)$ and the levels of development of the province was lower. There was no correlation between number of midwives per 10000 population ( $r=-0.246$ and -0.086$)$ and the economic development ranking of the province. According to these findings, the human resources for health, especially the number of pharmacists, dentists and doctors could be taken into account in the research on the economic development ranking.

\section{INTRODUCTION}

In the context of development levels, there are two terms to determine the relative values of the countries, regions or provinces. One of these terms is; "economic development" and the other is "economic growth". Although both these concept are seen as synonymous, they contains different structures (Küçükkalay, 2001). 
Economic growth is an important factor to increase the society's well-being. It is the increase in income per capita level and production capacity in a certain time. Economists use GDP, GNI and $\mathrm{NI}$ expressed as both absolute and relative sizes and per capita to measure economic growth. When economic growth rate of country is faster than past periods, the production of goods and services and the potential average standard of living rise (Küçükkalay, 2001, Haller, 2012).

While economic growth is about the increase in production of goods and services, economic development has a larger scope. It represents the increase in the field of social welfare such as economic, social, political and spiritual life of human. Economic development is concerned with both the quantitative side of economic level and qualitative side of economy and society. Therefore, it includes some specific changes in economic and social life such as education level, population growth, unemployment rate and infrastructure facilities and health status (Haller, 2012).

As seen, economic development is connected with the improvements in health. So some indicators such as health expenditures per capita, out of pocket, health expenditures, vaccination rates, number of physicians and nurses, life expectancy and infant, child and maternal mortality rates are considered as the most important determinants of economic development (Joumard et al., 2008). Especially the variations of sizes, distribution and composition of health care workforce are so critical to the determine development level of a country. Because, number of health workers shows the capacity of the country to provide delivery and interventions that improve the health status of citizens (Kabane et al., 2006).

In this context health status, human resources for health and economic development were argued in the literature part of this study. And then, a survey was performed to assess the causal relationship between economic development and human resources for health. The survey results are expected to provide important information on choosing indicators of human resources for economic development researches.

\section{LITERATURE SURVEY}

Health status has the main effect on economic development because of the healthier peoples are more productive, robust and active. They earn higher wages and salaries and also they less likely to be absent from work. In this regard, they provide more economic benefits to the country's economy (Bloom, Canning, and Sevilla, 2003).

When researchers examine the link between health status and economic development, they usually use two types of health measures: health inputs and health outcomes. Inputs are the physical indicators that include nutrition, exposure to pathogens, and the availability of medical care. The number of human resources for health per capita and number of hospital or hospital beds are the examples for the availability of medical care. Health outcomes include some health indicators such as life expectancy, infant and maternal mortality rate e.i. (Weil, 2005; Joumard et al, 2008; Kabane et al., 2006) .

As seen above, human resources for health are one of the key indicators to determine economic development. As health investments $\backslash$ health workers reduce the negative 
health outcomes such as maternal, infant and child mortality rates and increase the immunization rates (Amiria and Gerdtham, 2013). And then these changes improve the health level, efficiency of health and lead to higher economic growth and development. That is; investments in human resources for health can provide returns in terms of economic improvement.

The fulfillment of the efforts to increase immunization and to reduce the mortality rate, cannot be carried out without health workers like doctors, nurses, midwives, pharmacist, public health specialists, health educationalists and media experts. The health system also needs the services of health planners, health economists and accountants (Speybroeck et al, 2006; Annand and Baminghausen, 2007). Despite this, especially physicians, nurses and mid-wives are used in international comparisons (WHO, 2006). However, to collect information on all other of the health professionals like dentist and pharmacist can also be important (Pan American Health Organization, 2011). Because health improvement efforts cannot be performed without physical or mental activities of dentists and pharmacists as well as doctors and nurses.

In Turkey, there are a few institutional studies on economic development ranks of provinces. The firsts report was conducted by State Planning Organization named "Study on Socio-Economic Development Ranking of Provinces and Regions" is (Dinçer et al, 2003). The second report is "Socio-Economic Development Ranking of Provinces and Regions," published in 2013 by the Republic of Turkey Ministry of Development. "Research on Development Level of Provinces with 2010 and 2012 Data” published in 2014 by the Turkey İşbank is the last institutional survey on economic development of provinces.

Indicators of health care professionals which were used to determine the level of economic development in all these three reports show some differences. For example, State Planning Organization used number of physician per 1000 population, density of dentist, number of pharmacist per 1000 population and nurse to population ratio to calculate the economic development level of provinces (Dinçer et al, 2003). Conversely, number of physician per ten thousand people, number of dentist per 1000 population and number of pharmacist per 1000 population were used in Socio-Economic Development Ranking of Provinces and Regions. Research on Development Level of Provinces with 2010 and 2012 Data was used only the number of physician per 1000 population.

Assessing the impact of human resources for health on economic development ranks is major important to account of geographic distribution of health workers and policy issues such as determining priorities on human resources for health, allocation of health workers and deciding to health investment. Most studies have examined the relationship between health outcomes and human resources (Amiria and Gerdtham, 2013; Annand and Baminghausen, 2007). But unfortunately, only a few studies have investigated the link between and health professionals and economic development and growth (Mayer, 2001; Bigbee, 2008). So more investigation must be done about the effects of human resources for health on economic development in different level such as countries, provinces or households. Therefore, the aim of this study was to assess the relationship between the health workforce per 1000 population and economic development levels of provinces in Turkey. 


\section{DATA AND METHODOLOGY}

The sample consisted of all 81 provinces of Turkey.. Data on the ranks of economic developments of provinces were obtained from two reports; Socio-Economic Development Ranking of Provinces and Regions, computed by the Republic of Turkey Ministry of Development and Research on Development Level of Provinces with 2010 and 2012, published by Turkey Işsbank. In these reports, 2010 data had been used. So, for comparison purposes, number of human resources for health for 2010 were included in the analysis.

Data sheet on the human resources for health by provinces was obtained from the datasets of Turkish Statistical Institute (TSI). All physicians (general practitioner, assistant and specialist), pharmacist, dentist, nurse and midwife were included in the analysis. The numbers of health personnel per 10000 population were found by dividing the number of health workers provinces of the to population of the cities in the same source.

Correlation analysis was conducted to investigate relationships among variables. The data were analyzed using two-tailed Spearman's rank order correlations due to the ordinal level of the ranking data to a level of significance of $p<.05$.

\section{EMPIRICAL FINDINGS}

In Table 1, development ranking of provinces in two reports and number of human resources for health per 10000 population were given. According to province development ranking in these two reports, Istanbul, Ankara and Izmir are the most developed provinces while the less developed provinces are Hakkari and Muş in Turkey in 2010.

In Table 1, when the number of health staff per 10000 population was examined, it was found that physician density was the lowest in cities like Şırnak $(6,02)$ and Hakkari $(6,92)$ and the highest in cities like Ankara $(30,24)$ and Edirne $(26,64)$. While nurse density was the lowest in Şırnak $(7,67)$ and Mardin $(7,88)$, this ratio was highest in Trabzon $(23,01)$ and Ankara $(21,04)$. Of the top three provinces with the highest pharmacist-to-population ratios were Muğla $(5,28)$, Antalya $(4,81)$ Ankara $(4,76)$ and the lowes three provinces were Hakkari $(0,6)$, Şırnak $(1,16)$ and Muş $(1,2)$.

Descriptive statistics of 81 provinces by human resources for health are outlined in Table 2. According to findings, average pharmacist density (Mean $=3,04 ; S D \pm 0,99$ ) and average dentist per 10000 population (Mean=1,99; SD $\pm 0,84$ ) are the lowest in Turkey, while the average nurse-to-population ratio was highest (Mean=13,82; SD $\pm 3,3284$ ). 
Table 1: Development Ranks and Human Resources for Health to Population Ratios of Provinces

\begin{tabular}{|c|c|c|c|c|c|c|c|c|c|c|c|c|c|c|c|}
\hline 䓂 & 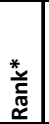 & 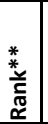 & $\begin{array}{l}\frac{c}{\frac{\pi}{u}} \\
\frac{0}{n} \\
\frac{c}{a}\end{array}$ & 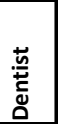 & 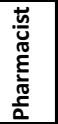 & 岕 & 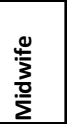 & 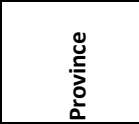 & 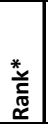 & 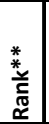 & $\begin{array}{l}\frac{c}{0} \\
\frac{\mathrm{d}}{\mathrm{N}} \\
\frac{\mathrm{v}}{\mathrm{N}} \\
\frac{\mathrm{c}}{\alpha}\end{array}$ & 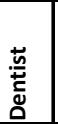 & $\begin{array}{l}\underline{\frac{n}{5}} \\
\stackrel{\pi}{5} \\
\frac{5}{\pi} \\
\frac{\pi}{\alpha}\end{array}$ & $\begin{array}{l}\stackrel{0}{\tilde{n}} \\
\mathbf{z}\end{array}$ & $\begin{array}{l}\stackrel{0}{*} \\
\stackrel{3}{3} \\
\stackrel{0}{\Sigma}\end{array}$ \\
\hline ADANA & 16 & 8 & 15,18 & 2,56 & 3,17 & 12,76 & 6 & K.MARAŞ & 60 & 42 & 9,89 & 1,42 & 2,4 & 11,23 & 6,46 \\
\hline ADIYAMAN & 66 & 65 & 8,14 & 1,1 & 2,18 & 8,8 & 5,7 & KARABÜK & 28 & 37 & 11,55 & 2,64 & 4,04 & 15,42 & 8,13 \\
\hline AFYON & 43 & 39 & 12,34 & 1,45 & 3,3 & 13,69 & 8,19 & KARAMAN & 32 & 34 & 9,2 & 1,89 & 4,21 & 13,88 & 6,83 \\
\hline AĞRI & 79 & 78 & 6,31 & 0,61 & 1,24 & 9,89 & 6,68 & KARS & 68 & 74 & 8,32 & 1,06 & 1,42 & 9,78 & 8,62 \\
\hline AKSARAY & 55 & 56 & 9,38 & 1,54 & 3,23 & 10,65 & 6,46 & KASTAMONU & 47 & 53 & 10,63 & 1,83 & 3,43 & 16,89 & 6,39 \\
\hline AMASYA & 37 & 48 & 9,83 & 2,27 & 3,46 & 15,89 & 8,63 & KAYSERI & 17 & 14 & 16,15 & 2,08 & 3,22 & 16,3 & 6,93 \\
\hline ANKARA & 2 & 2 & 30,24 & 4,4 & 4,76 & 21,4 & 5,92 & KIRIKKALE & 41 & 47 & 22,16 & 1,74 & 3,72 & 16,3 & 8,68 \\
\hline ANTALYA & 5 & 4 & 15,72 & 3,73 & 4,81 & 14,57 & 7,4 & KIRKLARELI & 15 & 28 & 10,73 & 3 & 4,03 & 11,78 & 8,86 \\
\hline ARDAHAN & 71 & 81 & 9,2 & 1,23 & 1,8 & 12,9 & 7,21 & KIRŞEHIR & 40 & 55 & 10,32 & 1,8 & 3,47 & 13,39 & 10,46 \\
\hline ARTVIN & 44 & 50 & 10,68 & 2,19 & 2,73 & 18,21 & 10,44 & KiLis & 63 & 68 & 8,93 & 1,22 & 2,76 & 9,1 & 6,25 \\
\hline AYDIN & 19 & 21 & 14,76 & 3,2 & 4,67 & 15,06 & 8,32 & KOCAELI & 4 & 6 & 13,14 & 2,71 & 2,72 & 14,68 & 6,6 \\
\hline BALIKESIR & 22 & 17 & 10,31 & 2,4 & 3,97 & 13,01 & 10,52 & KONYA & 20 & 10 & 13,9 & 2,15 & 3,34 & 12,14 & 6,73 \\
\hline BARTIN & 48 & 49 & 10,55 & 1,6 & 3,46 & 15,87 & 6,87 & КÜTAHYA & 38 & 33 & 9,47 & 1,39 & 2,88 & 13,79 & 7,37 \\
\hline BATMAN & 70 & 60 & 9,49 & 0,82 & 2,16 & 9,9 & 4,41 & MALATYA & 42 & 32 & 16,89 & 1,85 & 2,81 & 20,66 & 10,53 \\
\hline BAYBURT & 64 & 71 & 11,15 & 1,48 & 2,15 & 11,96 & 5,64 & MANISA & 23 & 18 & 11,82 & 2,16 & 3,48 & 12,25 & 7,13 \\
\hline BiLECIK & 27 & 45 & 8,3 & 1,6 & 2,44 & 9,58 & 6,57 & MARDIN & 74 & 64 & 7,35 & 1,11 & 1,58 & 7,88 & 5,47 \\
\hline BINGÖL & 72 & 73 & 8,07 & 0,9 & 1,61 & 12,46 & 9,41 & MERSIN & 24 & 11 & 12,76 & 2,17 & 3,33 & 13,16 & 8,54 \\
\hline BitLis & 76 & 77 & 7,06 & 1,03 & 1,31 & 11,01 & 5,54 & MUĞLA & 8 & 7 & 12,05 & 3,33 & 5,28 & 16,88 & 10,37 \\
\hline BOLU & 11 & 24 & 19,03 & 2,95 & 3,91 & 18,55 & 7,3 & MUŞ & 81 & 80 & 7,27 & 0,71 & 1,2 & 11,5 & 6,22 \\
\hline BURDUR & 26 & 38 & 10,93 & 2,2 & 4,52 & 16,19 & 14,02 & NEVŞEHIR & 36 & 41 & 11,05 & 1,88 & 3,9 & 12,15 & 7,83 \\
\hline BURSA & 6 & 5 & 14,05 & 2,94 & 3,35 & 14,13 & 6,57 & NiĞDE & 56 & 61 & 9,14 & 1,3 & 2,84 & 11,69 & 8,88 \\
\hline ÇANAKKALE & 14 & 23 & 12,95 & 2,63 & 3,63 & 15,8 & 11,34 & ORDU & 61 & 57 & 9,86 & 1,59 & 3,03 & 15,06 & 9,54 \\
\hline ÇANKIRI & 54 & 70 & 10,83 & 2,35 & 3,29 & 11,73 & 7,65 & OSMANIYE & 53 & 52 & 10,12 & 1,67 & 3,09 & 12 & 8,53 \\
\hline ÇORUM & 50 & 54 & 10,12 & 1,91 & 2,93 & 11,26 & 7,64 & Rize & 34 & 40 & 13,67 & 2,25 & 3,13 & 17,05 & 7,57 \\
\hline DENIZLi & 10 & 13 & 16 & 3,69 & 4,37 & 13,94 & 10,87 & SAKARYA & 18 & 16 & 10,18 & 2,82 & 2,61 & 9,91 & 6,53 \\
\hline DIYARBAKIR & 67 & 43 & 13,05 & 1,4 & 2,24 & 12,76 & 5,65 & SAMSUN & 33 & 22 & 16,9 & 3,3 & 3,38 & 17,3 & 6,71 \\
\hline DÜZCE & 35 & 35 & 17,06 & 2,28 & 3,19 & 14,43 & 5,15 & SiiRT & 77 & 75 & 8,68 & 0,96 & 2,06 & 11,57 & 5,62 \\
\hline EDIRNE & 12 & 25 & 26,64 & 2,56 & 4,25 & 21,16 & 10,68 & SINOP & 51 & 59 & 10,26 & 2,27 & 3,65 & 15,78 & 9,12 \\
\hline ELAZIĞ & 39 & 31 & 20,65 & 2,06 & 2,9 & 16,25 & 8,27 & SivAS & 49 & 46 & 16,71 & 1,56 & 2,71 & 15,51 & 7,89 \\
\hline ERZINCAN & 45 & 51 & 9,82 & 1,73 & 2,36 & 15,56 & 8,22 & ŞANLIURFA & 73 & 44 & 7,97 & 0,76 & 1,79 & 9,11 & 4,71 \\
\hline ERZURUM & 59 & 36 & 18,15 & 1,92 & 2,13 & 15,2 & 7,49 & ŞIRNAK & 78 & 72 & 6,02 & 0,56 & 1,16 & 7,67 & 5,02 \\
\hline ESKiŞEHIR & 7 & 9 & 18,28 & 2,71 & 4,41 & 18,45 & 7,73 & TEKIRDAĞ & 9 & 15 & 9,9 & 2,57 & 3,33 & 10,37 & 6,75 \\
\hline GAZIANTEP & 30 & 12 & 11,34 & 1,19 & 2,46 & 12,1 & 5,56 & TOKAT & 57 & 58 & 11,61 & 1,31 & 2,98 & 14,32 & 8,68 \\
\hline GIRESUN & 52 & 62 & 10,85 & 1,57 & 3,36 & 19,53 & 11,23 & TRABZON & 31 & 19 & 19,33 & 2,46 & 3,89 & 23,1 & 8,46 \\
\hline GÜMÜŞHANE & 62 & 69 & 10,49 & 2,31 & 2,7 & 15,82 & 5,94 & TUNCELI & 58 & 63 & 11,86 & 1,83 & 2,35 & 15,52 & 20,21 \\
\hline HAKKARI & 80 & 79 & 6,92 & 0,52 & 0,6 & 10,51 & 5,65 & UŞAK & 25 & 30 & 10,89 & 2,31 & 3,67 & 16,92 & 14,17 \\
\hline HATAY & 46 & 20 & 9,99 & 2,13 & 3,03 & 9,57 & 5,65 & VAN & 75 & 66 & 11,46 & 0,95 & 1,34 & 9,2 & 5,18 \\
\hline IĞDIR & 69 & 76 & 8,68 & 1,08 & 1,95 & 10,74 & 8,3 & YALOVA & 13 & 27 & 11,49 & 3,04 & 4,22 & 12,32 & 6,18 \\
\hline ISPARTA & 21 & 26 & 20,5 & 2,54 & 4,39 & 17,42 & 12,65 & YOZGAT & 65 & 67 & 10,46 & 1,32 & 2,29 & 10,57 & 7,04 \\
\hline ISTANBUL & 1 & 1 & 16,95 & 3,64 & 3,77 & 12 & 3,38 & ZONGULDAK & 29 & 29 & 15,94 & 2,16 & 2,61 & 18,38 & 7,34 \\
\hline izMiR & 3 & 3 & 22,26 & 4,08 & 4,66 & 16,33 & 6,25 & \multicolumn{8}{|c|}{ * Ministry of the Republic of Turkey Development Ranking } \\
\hline
\end{tabular}


Table 2: Descriptive Statistics of 81 Provinces by Human Resources for Health

\begin{tabular}{|l|c|c|c|c|c|}
\hline & $\mathbf{N}$ & Minimum & Maximum & Mean & Std. Deviation \\
\hline Physician & 81 & 6,02 & 30,24 & 12,4481 & 4,55407 \\
\hline Dentist & 81 & 0,52 & 4,4 & 1,9953 & 0,84494 \\
\hline Pharmacist & 81 & 0,6 & 5,28 & 3,0401 & 0,99148 \\
\hline Nurse & 81 & 7,67 & 23,1 & 13,8212 & 3,32222 \\
\hline Midwife & 81 & 3,38 & 20,21 & 7,798 & 2,49109 \\
\hline
\end{tabular}

In Table 3, as seen, Spearman's correlation analyses technique was used to examine the relations between economic development and human resources for health indicators such as the number of physician per 10000 population, number of dentist per 10000 population, number of pharmacist 10000 population, number of nurse and midwife per 10000 population.

Table 3: Correlations Among Variables

\begin{tabular}{|l|c|c|}
\hline & $\begin{array}{c}\text { Republic of Turkey } \\
\text { Ministry of Development } \\
\text { Ranking }\end{array}$ & Turkey İşbank Ranking \\
\hline Physician &,$- 680^{* *}$ &,$- 698^{* *}$ \\
\hline Dentist &,$- 890^{* *}$ &,$- 792^{* *}$ \\
\hline Pharmacist &,$- 810^{* *}$ &,$- 684^{* *}$ \\
\hline Nurse &,$- 507^{* *}$ &,$- 422^{* *}$ \\
\hline Midwife & $-0,246^{*}$ & $-0,086$ \\
\hline
\end{tabular}

**. Correlation is significant at the 0.01 level (2-tailed).

*. Correlation is significant at the 0.05 level (2-tailed).

The correlation analyses indicated that it was highly correlation between the development level and number of dentist per 10000 population ( $r=-0,890$ and $-0,792)$ and number of pharmacists per 10000 population $(r=-0,810$ and $-0,684)$ and moderate correlation between the level of economic development and number of physician per 10000 population ( $r=-0,680$ and $-0,698)$. The correlations between number of nurse 10000 population ( $r=-0,507$ and $-0,422)$ and the levels of development of the province were lower. There was no interaction between the number of midwives per 10000 population $(r=-0,246$ and $-0,086)$ and economic development ranking. As the human resources for health to- population ratios increased, the province development rank improved. 
These results confirm that the most important factor contributing to variation of economic development level across provinces, was the density of pharmacists. Friesner et al. (2009) found out that pharmacists working in outpatient and retail settings were often geographically separate from the other sources of health care, and this made the economic impact of these pharmacists on the regional economy distinct and more easily quantified compared to other types of health professionals. Dinçer et al. (2003) and Ministry of the Republic of Turkey Development (2013) used number of pharmacist and dentist per ten thousand people to calculate the economic development level of provinces.

Physicians and nurses also affect the development level of provinces in moderate level. In a report made by Ministry of Health of Turkey (2007), it was found out that there was a moderate level of correlation between the specialist physician $(r=-590)$, general physicians $(r=-480)$, and nurses - midwives ( $r=-420)$ and per capita GDP. Bigbee (2008) also found that the physician-to-population and nurse-to-population ratios were also significantly related to state health ranking in moderate level in America. In that study, the total physician-to-population ratio $(r=-491, p=.000)$, nurse-to-population ratio and overall state health ranking $(r=-446, p=.001)$ and the primary care physician-to-population ratio ( $r=-$ $613, p=.000$ ) were significantly related to the overall state health rankings.

\section{CONCLUSION}

This study was conducted in order to assess the relationship between density of human resources for health and development levels of provinces in Turkey. Our results confirm that the most important factors contributing to variation of economic development level across provinces were the number of pharmacist per ten thousand people and number of dentist per capita. Furthermore, it was found out moderate important factors contributing to variation of economic development level across provinces were the numbers of physician and nurse.

According to these findings, investment in human resources for health can be considered as part of economic development and growth strategies. The human resources for health, especially the number of physician, number of pharmacists and number of dentist could be taken into account to the research on the development ranking, and these indicators could be used as substitution variables of the development levels.

\section{REFERENCES}

Amiri, A., and Gerdtham, U.G. (2013) Impact of Maternal and Child Health on Economic Growth: New Evidence Based Granger Causality and DEA Analysis. Partnership for Maternal, Newborn \& Child Health, USA, p.21-22.

Anand, S, Baminghausen, (2007). T. Human resources for health and vaccination coverage in developing countries. Lancet,. 14, (369), p.1277-85.

Bigbee, J.L. (2008). Relationships Between Nurse- and Physician-to-Population Ratios and State Health Rankings Public Health Nursing. 25(3), p.244-252.

Bloom, D.E., Canning, D. and Sevilla J. (2003). The Effect of Health on Economic Growth: A Production Function Approach. World Development 32(1), p. 1-13. 
Dinçer, B., Özaslan, M. and Kavasoğlu, T.(2003). Illlerin ve Bölgelerin Sosyo-Ekonomik Gelişmişlik Sıralaması Araştırması. DPT Yayınları No: 2671, Ankara, 2003, p.10.

Friesner, D., Rosenman, R., Bozman, C.S. Economic Impact of Pharmacy Graduates on a Regional Economy. (2009). American Journal of Pharmaceutical Education, 73 (3), p.1-8.

Haller, A.P. (2012). Concepts of Economic Growth and Development. Challenges of Crisis and of Knowledge. Economy Transdisciplinarity Cognition, 15(1), p. 66-71.

Joumard, I., Andre, C., Nicq, C. and Chatal, O. (2008). Health Status Determinants: Lifestyle, Environment, Health Care Resources and Efficiency", OECD Economics Department Working Papers, No. 627, OECD Publish.

Kabene, S.M., Orchard, C., Howard, J.M., Soriano, M.A. and Leduc, R. (2006). The importance of human resources management in health care: a global context. Human Resources for Health, 4(20), p.1- 17.

Küçükkalay, M. (2001). İktisadi Kalkınma ve Nüfus Artışı Paradoksu Üzerine Yorumlar. Osmangazi Üniversitesi, Sosyal Bilimler Enstitüsü Dergisi, 1, p.59-73.

Mayer, D. (2001). The Long Term Impact of Health on Economic Growth in Latin America. World Development. 29(6), p.1025-1033.

Pan American Health Organization. (2011). Handbook for Measurement and Monitoring Indicators of the Regional Goals for Human Resources for Health: A Shared Commitment. PAHO, Washington, D.C, p..3.

Speybroeck, N., Kinfu, Y., Dal Poz, M.R. and Evans, D.B. (2006). Reassessing the relationship between human resources for health, intervention coverage and health outcomes. Geneva: World Health Organization Publications; p.1.

Ministry of Health of Turkey (2007). Analysis Of Current Situation For Human Resources In Health Sector. Ankara: HM Publication, p.13.

Ministry of the Republic of Turkey Development) (2013). Illerin Ve Bölgelerin Sosyo-Ekonomik Gelişmişlik Sıralaması Araştırması. Ankara: Türkiye Kalkınma Bankası Bölgesel Gelişme ve Yapısal Uyum Genel Müdürlüğü Yayınları, Ankara, p.20

Turkey İş Bank. (2014). 2010 ve 2012 Verileriyle Türkiye'de illerin Gelişmişlik Düzeyi Araştırması. İktisadi Araştırmalar Bölümü https://ekonomi.isbank.com.tr/UserFiles/pdf/ar 03 2012.pdf.

Türkiye İstatistik Kurumu. www.tuik.gov.tr. Access:Mart 2011.

Weil, D. (2005). Accountıng For The Effect Of Health On Economıc Growth. NBER Workıng Paper Series, 11455. http://www.nber.org/papers/w11455. Access: 06 Mart 2015.

WHO. (2006). The World Health Report: Working together. WHO Publication, Genova, p.xviii.

Zurn, P., Dal Poz, M.R., Stilwell, B. and Adams, O. (2004). Imbalance in the health workforce. Human Resources for Health, 2(13), p. 1-12. 